\title{
THE DYNAMICS OF CHORAL CULTURE DEVELOPMENT IN CHINA IN THE 1930S ON THE EXAMPLE OF HUANG TZI'S ORATORIO ETERNAL REGRET
}

Summary: Choral music in China is a dynamically developing form of contemporary musical art. Scientific works devoted to the Chinese choral culture consider the 1930s of the 20th century as the most productive period in the development of this branch of musical creativity. The article examines the phase of the active entry of Chinese choral music into the sphere of the oratorio genre, which is directly related to the name of the great Chinese composer - Huang Tzi. It also highlights the issues of the country's political life in the 1930s, which actively influenced the creation of nationwide singing movements and new choral works in the country.

The oratorio genre, the genesis of which refers us to the European religious musical tradition of the 17th century, spread in China owing to the massive flow of Chinese intelligentsia to the territory of Western states throughout the entire beginning of the 20th century. In the article, the actualisation of the oratorio and its interpretation in a new light is presented as the merit of Huang Tzi, whose civic position was directly related to the desire to preserve ethnic origins in Chinese music and to complement them with Western composing techniques organically. Having proved himself not only as a composer but also as a theorist and teacher, Huang Tzi devoted most of his life to educating a large number of music professors, initiating a progressive approach to music education. His desire to raise the level of the composing school in China made it possible

The choral art of China has come a long way. Developing from the early forms of school songs (shuetang yuege) to the heights of oratorical creativity, it made progress in the tragic era of the 1930s — the to enrich the repertoire of vocal and instrumental music with characteristics of the folk style.

The oratorio Eternal Regret presented in the article is a unique creation that organically combines ethnic music and Western composition techniques. In the story of Emperor Xuanzong and Yang Guifei (to the poems of Tang poet Bai Juyi), taken by the composer as the theme for the libretto, there is certain symbolism that has the conceptual plan of addressing the power to demonstrate the alleged results of Kuomintang's unclear policy. Thus, directly related to political cataclysms and their final embodiment in the form of the Sino-Japanese war (1937-1945), the oratorio Eternal Regret is presented in the article as a consolidating core that inspired the civilian masses to fight the Japanese invaders.

The analysis of Bai Juyi's original poem "Eternal Regret" and a fragmentary historical-stylistic and vocal-choral analysis of the oratorio have been carried out. The artistic features of individual parts of the oratorio, seven of which were completed by the composer, are revealed. Based on literary sources and theoretical research presented in the article, the author asserts the special role of the oratorio Eternal Regret in history and its far-reaching influence on the prospects for the development of the Chinese choir.

Keywords: Huang Tzi, Bai Juyi, choral genres in China, musical culture, oratorio, "Eternal Regret", composing techniques.

period of the Sino-Japanese War ${ }^{1}$. The first choral works of the early 20th century, based on borrowing materials from Western and Japanese songs, are now regarded as a preparatory stage for a qualitatively 
new phase in choral music development. The lyrical message, the description of natural landscapes and the light mood of the compositions were replaced by the complication of conceptions. At the same time, musical education was developing; the first conservatories started to open; art was moving into the field of writing complex choral works, which contributed to the popularisation of choral art in the country ${ }^{2}$.

The Mukden incident of 18 September 1931 and the subsequent Japanese army offensive set a precedent for creating nationwide "anti-Japanese" singing movements and "national salvation" movements The country's composers, helping the Communis Party fight against the Japanese invaders in every possible way, determined the change in the vector of cultural development in writing mass choral (anti-Japanese) songs. At the same time, an analysis of the works of modern researchers, including Wu Gen-Ir, Qian, Renkang, Wang Juipu, Wang Yuhe, and others, provides an extensive layer of information on the study of choral music of the 1930s, talking about this period as the time of the actualisation of military songs and the complication of compo sitional writing techniques with the subsequent ap pearance of the oratorio genre.

In this regard, special attention is given to the great Chinese composer - Huang Tzi (1904-1938), who responded to the call of the times. He was one of the direct initiators of the creation of the Anti-Japanese Union and the Union for the Salvation of the Nation on the basis of the National Conservatory of Music. However, the composer repeatedly said that the Chinese choral art should become in dependent - with its own characteristics and clearly manifested national traits ${ }^{4}$.

Prior to the events described below, it must be said that Huang Tzi received an outstanding ed ucation. After graduating from the Beijing Tsing hua Preparatory School, founded for people who are to continue their education in America, he often took part in school activities organised there with the assistance of the Christian Church. The in fluence of church music affected the fact that he subsequently began to study Western music in a standard and systematic way, continuing his studies at Oberlin College and Yale University (USA). Af-

2 Wu Gen-Ir. The Traditional Music of the Far East (China, Korea, Japan). St. Petersburg: Herzen Russian State Pedagogica 王瑞理境,《抗日战争歌曲集成》。花山文艺出版社,2003:2-3 4 贺绿汀. 回忆黄自先生. 乐坛, 1983.(8):3-8. ter receiving a bachelor's degree in musicology in 1929 and returning to his homeland in 1930, he began working at the National Conservatory of Music (Shanghai) at the invitation of Xiao Yumei, a composer and $f$ While teaching students about harmony, choral disciplines, counterpoint, instrumentation and composition (in addition to music history and solfeggio), Huang Tzi was indeed well acquainted with Western composing techniques and did not detract from their importance. Nevertheless, he considered it es pecially important to preserve the cultural "code" of the nation through its introduction into the musical culture of the country.

In every possible way, the composer tried to popularise ideas about the development of his, national music, with a change in the previous vector of de velopment, in which a tendency to copy Western and Japanese song tunes was clearly seen. Advocating the originality of his own choirs, Huang Tz was convinced that "...new music can only be created by composers who, possessing knowledge of Western technologies, share the fate of the Chinese people, their blood and soul" 5 . Owing to the observance of these statements, Huang Tzi was able to carry out the mission of combining traditional national creativity with the latest Western genre-style tendencies, relevant for Chinese musical art. As person who perfectly mastered the basics of West ern composition, Huang Tzi researched traditional Chinese music, ballads and poetry, wishing to cre ate a new national style of choral music that could increase the artistic level of works and the degree of complexity.

Literally in the first days after the proclamation of the creation of the Anti-Japanese Movement and the National Salvation Movement in 1932, Huang Tzi created the monumental work Eternal Regret the first Chinese oratorio for chorus, soloists and orchestra, in which, despite the content describing the events of bygone days, the analogy with the difficult events of the 1930 s is clearly seen. It should be noted that the idea of creating anti-Japanese songs allowed Huang Tzi to create not only the world's first Chinese oratorio but also to initiate the creation of a whole layer of anti-Japanese songs ${ }^{6}$. It was the oratorio Eternal Regret that be 5 李岗清. 探索创建我国民族乐派的先驱和一代宗师一黄自. 音乐 6. sistance, Agaainst the Enemed the first "anti-Japanese choir Re sistance Against the Enemy", followed by the creation of the
second choir of this kind, The Flag Fluttering in the Wind. came a unique and large-scale work, the first of its kind. Here the author skillfully turned to the style of the German song tradition, European romanticism, gracefully framing the plot of the poem "Eternal Regret" on the verses of the poet of the Tang era, Bai Juyi (772-846), (adapted for a libretto by Huang Tzi's contemporary, songwriter Wei Hengzhan)

Eternal Regret is an organic synthesis of music and text. Individual parts of the work, presenting melody, harmony and orchestration in the national style, appear very original today

Delving into the study of the storyline of the oratorio, it must be said that the content of the original plot (which was not distorted in the oratorio) takes us back to the reign of Emperor Xuanzong (685-762), who was a direct participant in the events described ${ }^{7}$. The main action takes place in 736 and begins with the story of the death of the beloved concubine of Emperor Xuanzong, Wu Guifei. The inability to come to terms with the fate of the beloved leads to the fact that the emperor loses peace. The introductory part of the plot describes the moment when the emperor meets Yang Yuhuan the wife of his son Li Mao. Blinded by her beauty and intelligence, the emperor, regardless of ethical manners, assigns her the court title of Guifei ${ }^{8}$. Falling in love with Yang Yuhuan, the emperor abandons all worries about political affairs while leading a very extravagant life. However, despite the deteriorating situation in the country with a widespread loss of authority, the emperor continues to try to charm Yang Guifei: in order to show his loyalty to the new concubine, Xuanzong appoints Yang Gu zhong, the elder brother of Yang Guifei, as prime minister, and important titles are confered upon several of her sisters.

Tenality of Yang Guzhong Bai Juyi demonstrated the character's negative traits. Without the proper qualifications for his position, violating the government's rules in every possible way, Yang Guzhong actively interacted with the court offcials, facilitating corruption and extortion. Ultimately, this was what led to a massive military uprising in 755 , threatening the political order throughou the country. With the active discontent of the rebe troops, the escort of Emperor Xuanzong rebelled on the way to Sichuan (in Maweypo, Shanxi province). Blaming the Yang family for the chaos, the re-

钱仁康. 《黄自的生活与创作》. 北京: 人民音乐出版

社, 1997:50-53.
The title of the Emperor's wife of the $1^{\text {st }}$ rank. bels executed Yang Guzhong and other members of the Yang family. The troops also demanded that Yang Guifei be put to death. To calm the army and keep his thron but to order her to commit suicide 9 .

Yang Guifei was one of the four beauties of ancient China. She received the recognition and love of the emperor for her beauty, and her beauty also became the cause of her death. The title bestowed on the young concubine by Xuanzong was the direct cause of the catastrophe that occurred not only in the family but also in the country. Here I would like to add that in 806 , when Bai Juyi began to write this story, his goal was to devalue Yang Guifei by showing her from a negative side. However, the incident of the great concubine was that she turned into hero for whom people felt special compassion. As a result, the long narrative lyric poem, praising the very idea of love, became a cultural monument with certain political overtones, forcing empathy with heroes through the centuries.

In addition, I would like to note that, besides describing the love tragedy that unfolded between the emperor and his son's wife, the consideration of such problems as social inequality can be traced in Bai Juyi's work: the sophistication of the imperial life as opposed to the extreme poverty of the com mon people. Bai Juyi's original poem was in three parts. The first part was devoted to the love story of Xuanzong and Yang Guifei. The second part contained a description of the uprising caused by the behaviour of Emperor Xuanzong, as well as the rebellion and the subsequent death of Yang Guifei In the death scene of Yang Guifei, the poet accurately described the characters' feelings, reflecting the inner struggle and despair of Emperor Xuanzong who did not want to kill his beloved but was forced to do so. This personal tragedy gave rise to the title of the poem - Eternal regret.

The next third part describes the emperor's return to the palace in Chang'an (now Xi'an). Sadness and longing for Yang Guifei, the inability to return her takes the emperor to the land of his dreams. In the last part of the poem, the poet conceived bright fairy-tale land, in which Emperor Xuanzong appears and where Yang Guifei is still alive. This meeting turns a love tragedy that happened in the real world into a story full of happiness in an illusory world ${ }^{10}$

9 朱金城.《白居易年谱》.上海:上海古籍出版社, 1982:100-108 


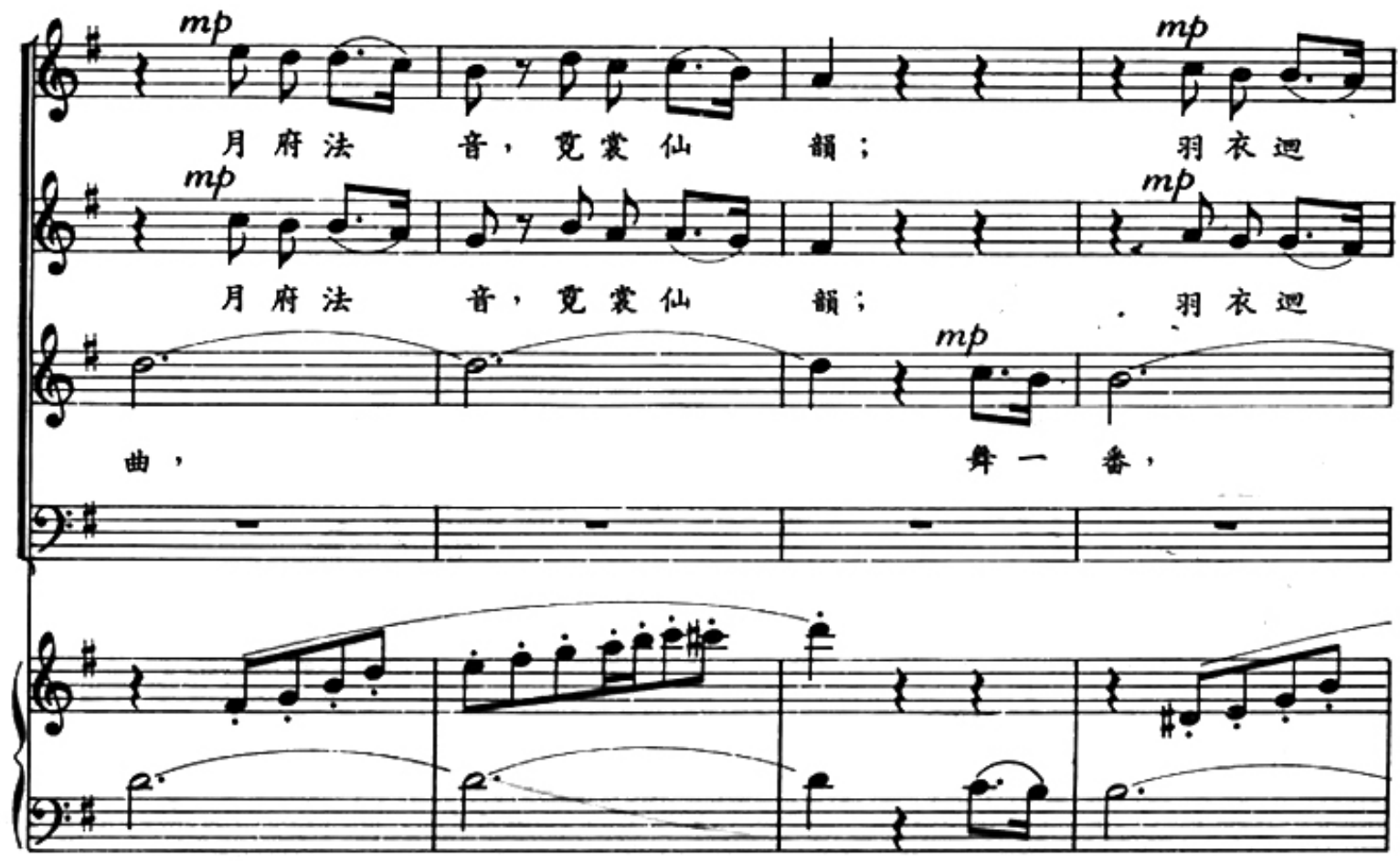

$=$

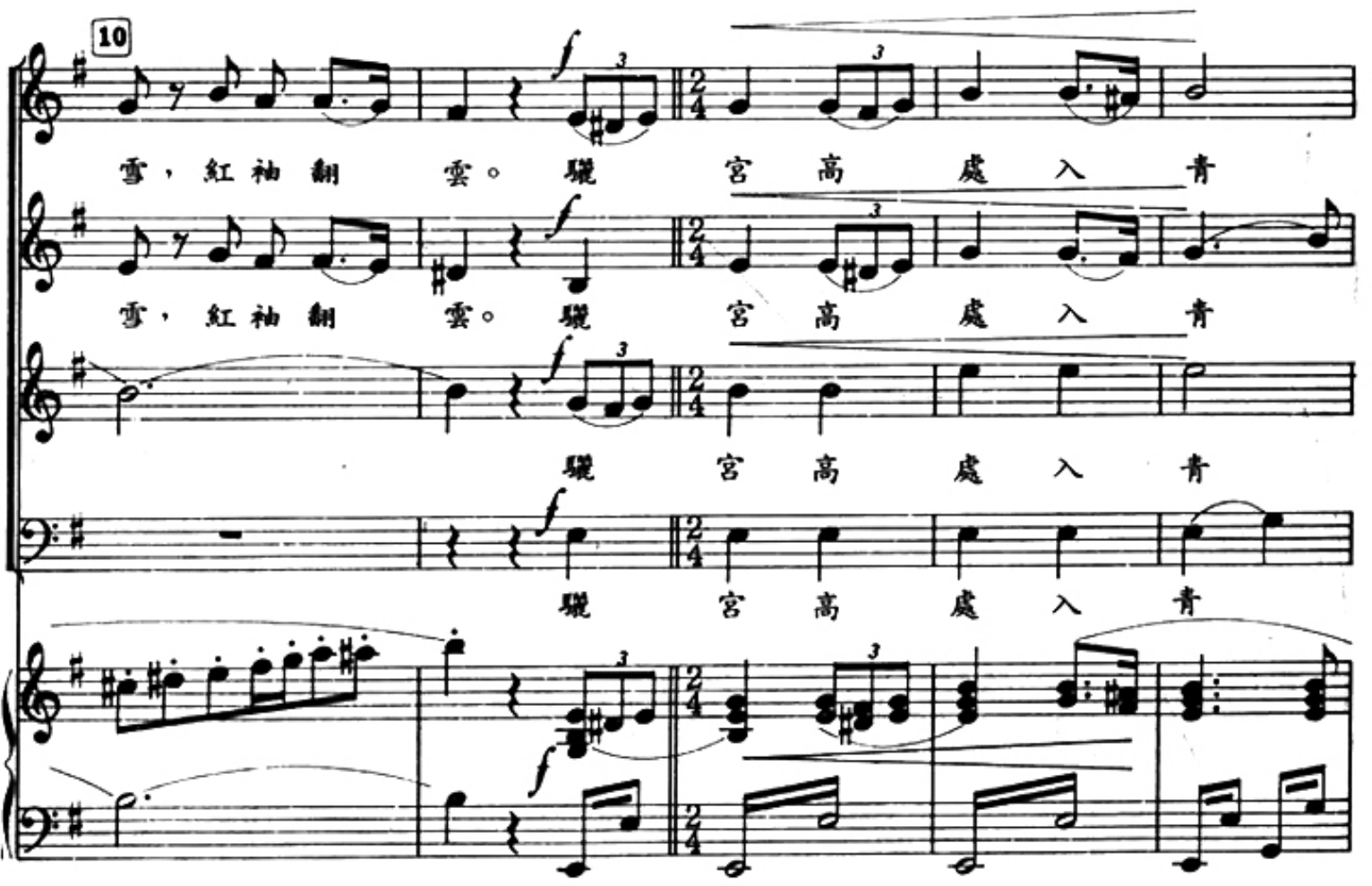

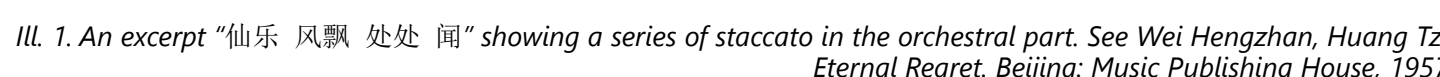

\section{(二) 七月七日長生殿}

Andante

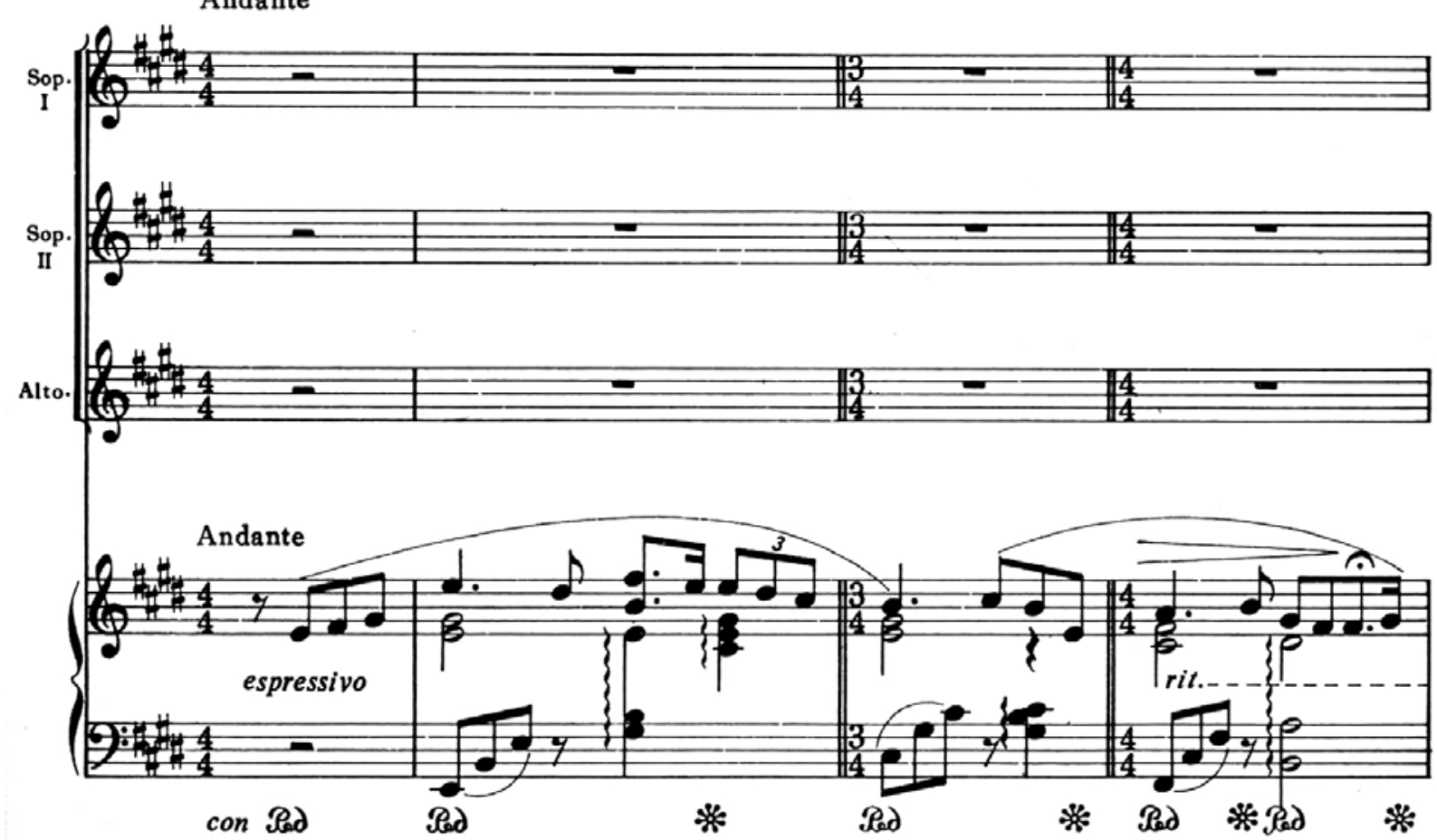

Ill. 2. An excerpt “七月 七日 长生 殿". See Wei Hengzhan, Huang Tzi. Eternal Regret. Beijing: Music Publishing House, 1957.

However, composer Huang Tzi made such an original choice of the story of Xuanzong and Yang Guifei as a theme for the libretto not as a praise of a poignant love story but rather as an appeal to power in order to demonstrate the results of Kuomintang's unclear policy, which could lead to a national catastrophe. The two excerpts from the male chorus in the third and fifth parts of the oratorio best convey the people's anxiety in the era of the 1930s. It is they that represent the patriotic call for salvation from the Japanese enemy troops.

Delving into the content of the oratorio Eternal Regret, it is essential to note that initially, it was divid ed into ten parts. The title of each part correspond ed to several lines of Bai Juyi's poems ${ }^{11}$. However out of ten, Huang Tzi managed to compose seven $(I, I I, I I I, V, V I, V I I I, X)$. This fact did not affect the integrity of the original concept: seven completed parts (which will be described below) conveyed the main content and scenes of the poem with its plot essence and integrated structure. The three unfinished parts were supposed to become solo items

11 钱仁康, 黄自的生活与创作》, 北京: 人民音乐出版社 $1997: 70$ without choral parts. Most likely, this was what affected their incompleteness.

In the first part, "The Sounds of Celestial Music, Blown into the Distance by the Wind", Huang Tzi used a simple three-part form. The part was composed for a four-part mixed choir, allegorically reflecting the atmosphere of the palace festival, with which the oratorio's act begins. Particular attention was paid to the opening of the orchestral part. A series of staccato, which is heard in the accompaniment in the 1st period, and barely audible, similar echoes in different parts of the 2 nd period figurative ly express the luxury of the imperial palace, where graceful ladies-in-waiting are dancing:

The second part, "In the Palace of Eternal Youth on the 7th Day of the 7th Moon", is structured using a complex three-part form and begins with an introduction by the orchestra conveying the theme of love:

The accompaniment is followed by a three-part female choir, reflecting all the beauty of a calm, warm night. Against their background, the solos of the soprano and baritone - the emperor and Yang Guifei, tell us about the oath of the beloved to each other and the heavy torment of their parting: 


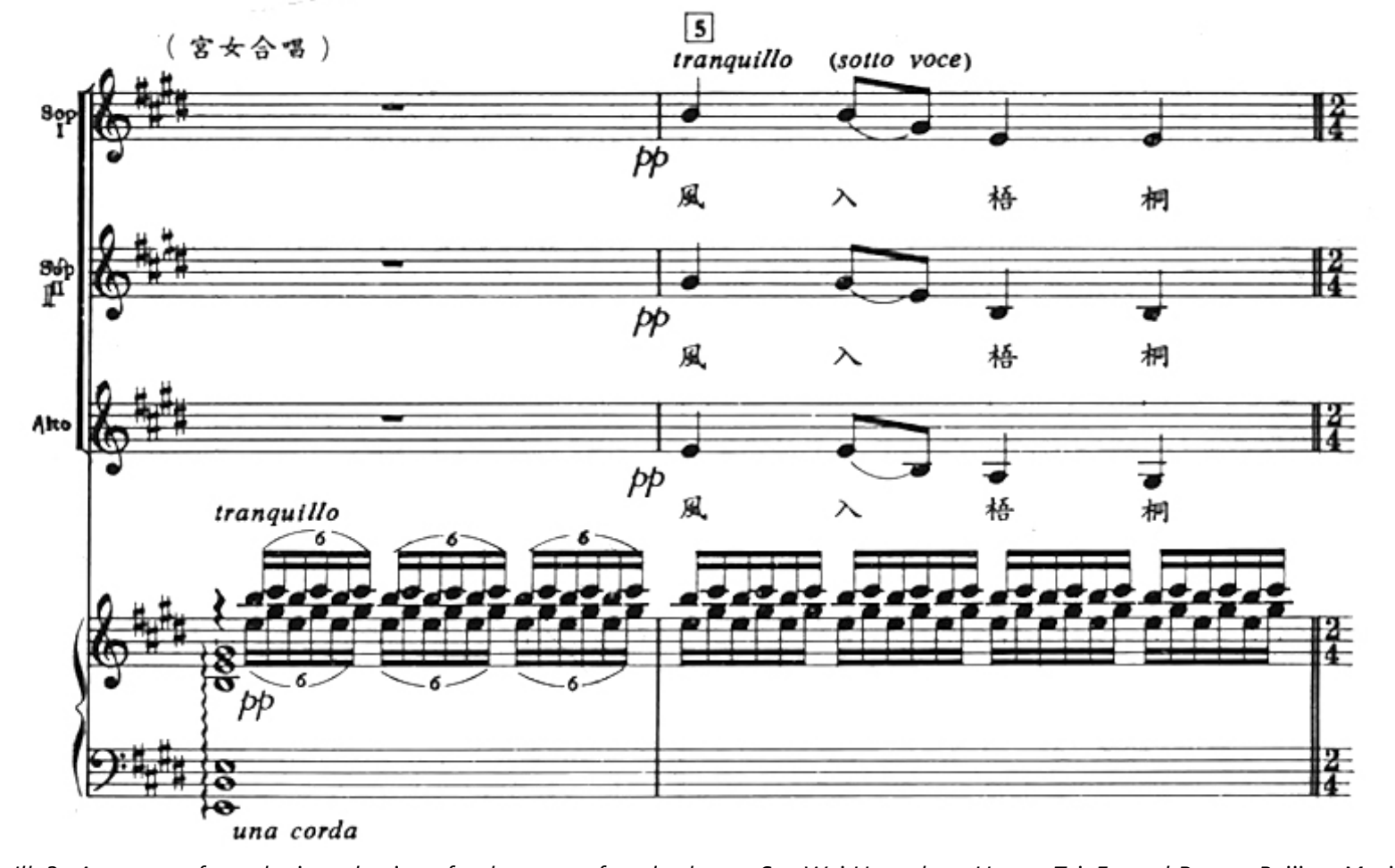

IIl. 3. An excerpt from the introduction of a three-part female chorus. See Wei Hengzhan, Huang Tzi. Eternal Regret. Beijing: Music
Publishing House, 1957.

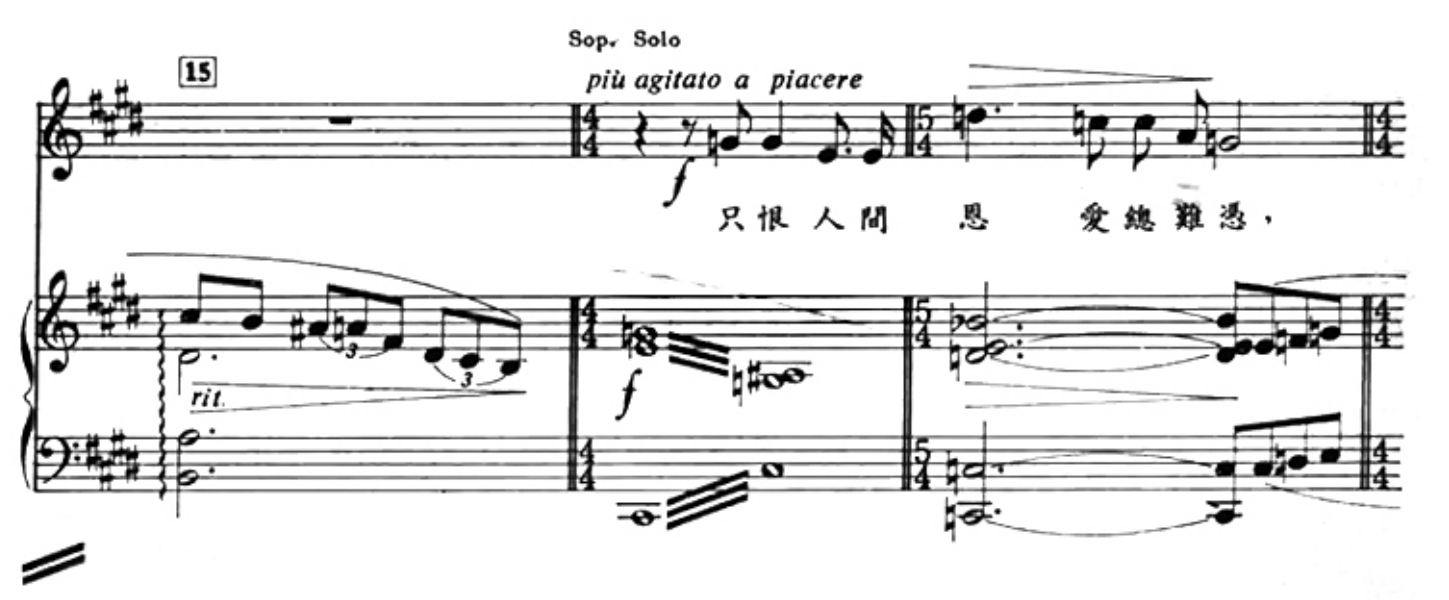

IIl. 4. The part of Yang Guifei, see ibid.

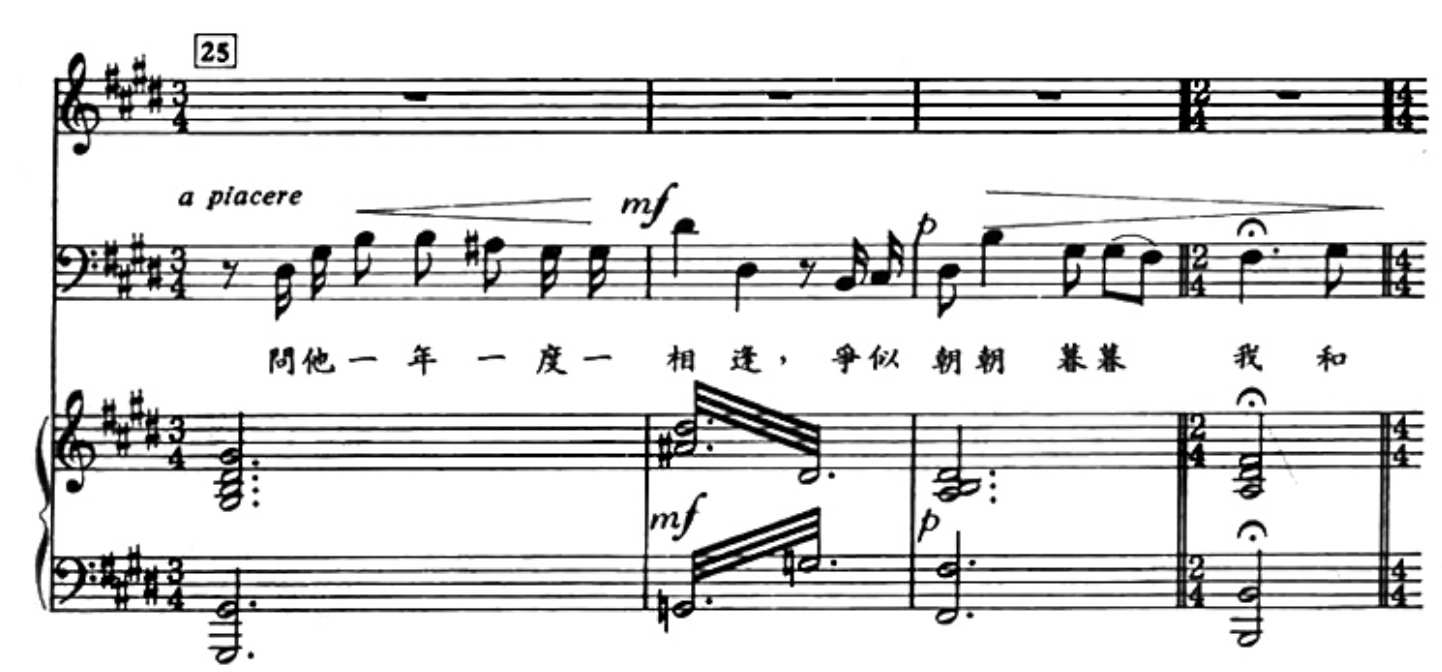

IIl. 5. The part of the Emperor, see ibid.
（三）漁陽策鼓動地來

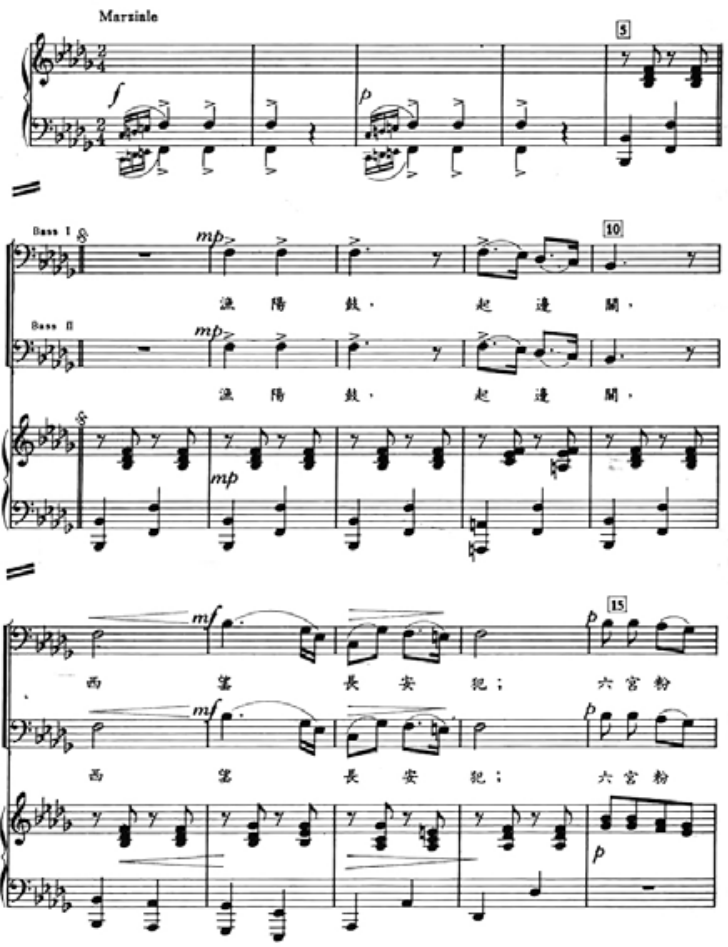

(2)

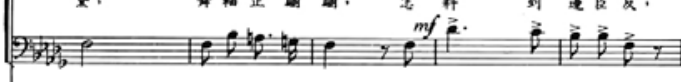

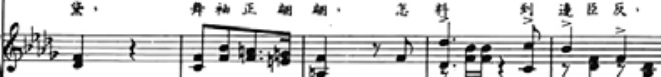

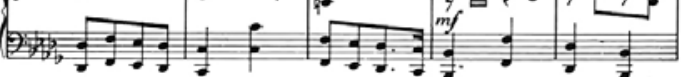

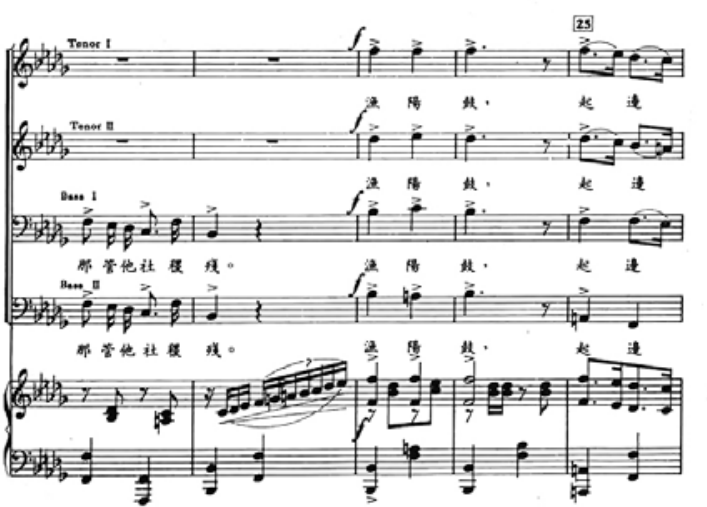

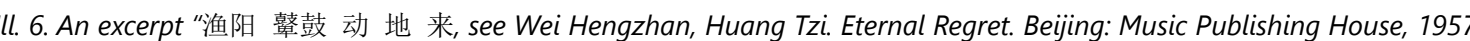

$$
\text { (五) 六軍不發無奈何 }
$$

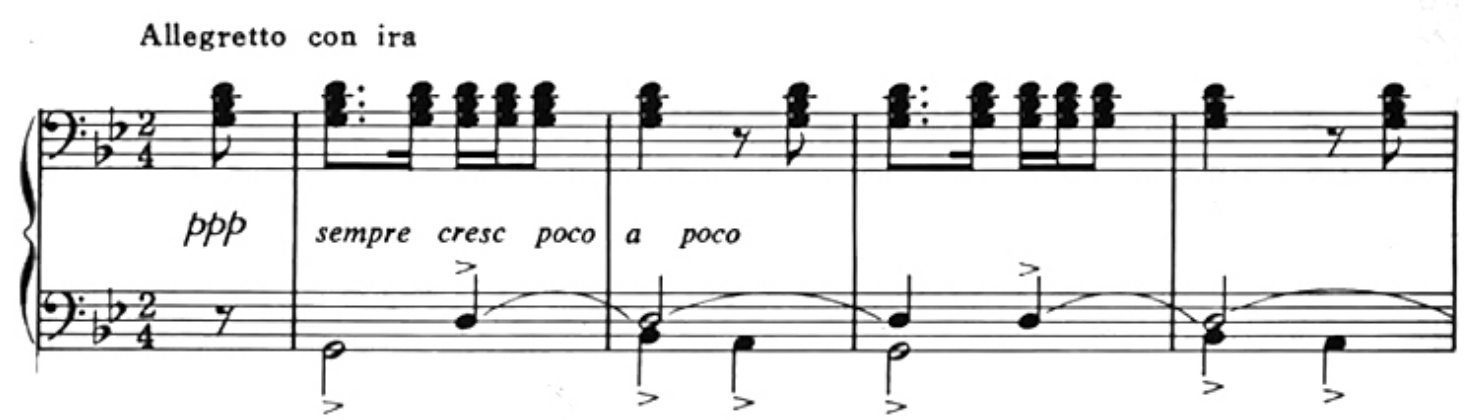

IIl. 7. An excerpt"六军不发无奈 何" illustrating dynamics. See Wei Hengzhan, Huang Tzi. Eternal Regret. Beijing: Music

The third part, "Battle Drums in Yuyang, Shaking Huang Tzi introduced polyphony, and the melody the Earth", differs from the first and the second one of the piece reflects deliberate drama:

in its warlike character, conveying a fighting spir- The fifth part, "The Emperor was Powerless when it. Here Huang Tzi used a three-part form to depict the Guards did not Obey Him", was written for a the scene with the military approaching the capital. four-part male choir: the rebel troops protest with First, we hear the tenor part (imitation of the scene a demand for the execution of Yang Guifei. We can of the approach of the rebel forces to the capital), say that this is where the culmination of the whole and then, echoing them, the four-part male choir. oratorio is seen. The intensity of the dynamics varThroughout the chorus, there is an artistic depic- ies from ppp to fff, which is characterised as the tion of the rebels' anger, expressing dissatisfaction apogee of resentment and anger. This feeling is with the behaviour of the emperor and the inaction consistent with the anti-Japanese enthusiasm of of the government in current affairs. In this section, the people in the 1930s. It is how Huang Tzi meta- 


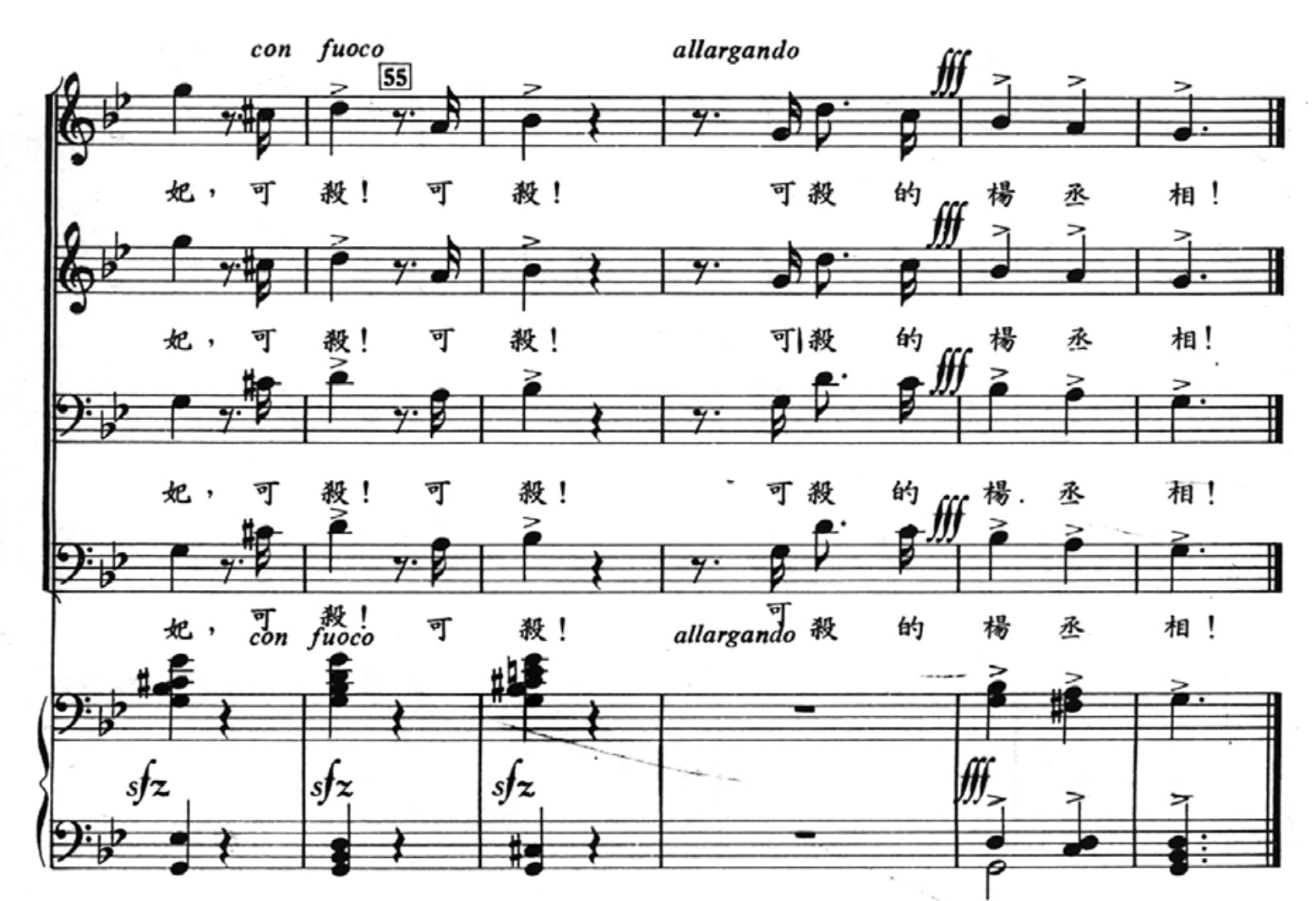

IIl. 8. An excerpt"六 军不发无奈 何" with an illustration of dynamics. See ibid.

(六)宛轉蛾眉.馬前死

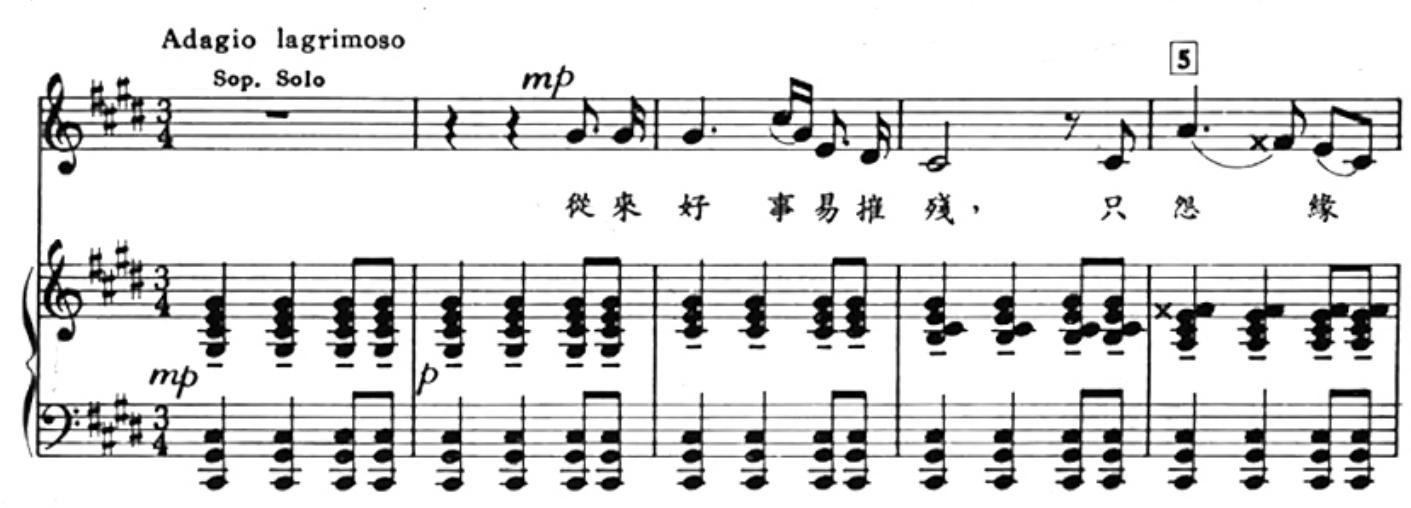

\section{$=$}

III. 9. An excerpt "宛转蛾眉马 前死. See Wei Hengzhan, Huang Tzi. Eternal Regret. Beijing: Music Publishing House, 1957

phorically declared the determination of the people to oppose Japan with all their hearts:

The next, sixth part, "The Suicide of Yang Guifei in Front of the Imperial Horse", tells about the tragic death of the concubine of the emperor, who was forced to order Yang Guifei to commit suicide in order to preserve the emperor's throne. Here the solo part is given to the soprano, and the whole

part is filled with a particular tragedy that characterises the end of the love story of the emperor and his beloved:

The remaining two parts, "A Fairy-tale Mountain in the Ocean of an Unprecedented Land" (VIII) and "Eternal Regret for an Unfulfilled Vow" (X), are of particular interest to us since it is here that Huang Tzi brought into implementation skilful Western com-

Andante sostenuto (八)山在虛無縹渺間

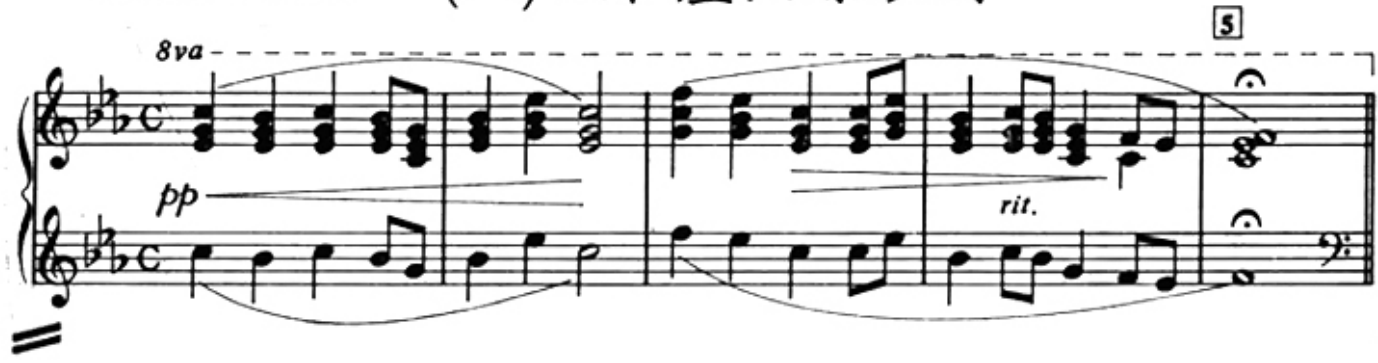

11l. 10. An excerpt “山在虚无 缥纱间” with an illustration of folk melody Qingping Diao in the orchestral part. See ibid.

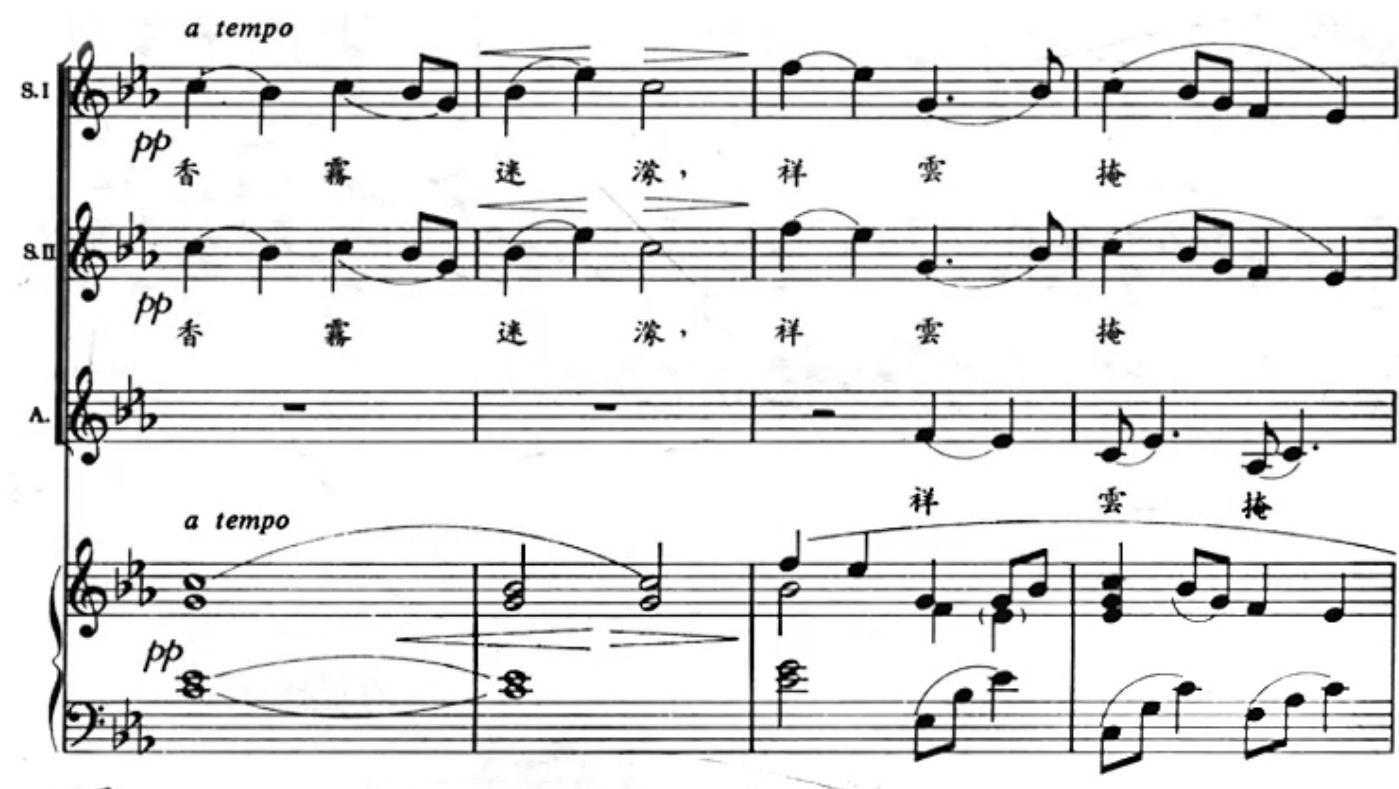

III 11. An excerpt"山在虚无 缰纱间" See Wei Hengzhan, Huang Tzi Eternal Regret. Beijing: Music Publishing House, 1957.

posing techniques, which gives the remaining two parts refined artistic charm. Gravitating towards various polyphonic techniques and borrowing them from European culture, Huang Tzi laid the foundations of vocal polyphony and harmonic thinking in the structure of the Chinese chorus, which can be clearly seen in the eighth part of Eternal Regret. Here the composer used a binary form and a three-part female choir, organically interspersed with the folk melody Qingping Diao ${ }^{12}$. In the opening melody of the eighth part, the composer used the pentatonic scale. It can be heard in the orchestral accompaniment, giving the melody a certain charm and mystery:

The laughter of the fairies of the sacred island of Penglai is heard in a three-part female choir. The string accompaniment performed by the first and second violins is clean and soft, creating a fantastic atmosphere of wonderland. The combination of folk song motifs with Western composing tech-

12 A popular Chinese folk melody during the Tang era. niques immerses the listener in the atmosphere of impossible fairy tale.

The tenth part is the final one. A four-part mixed chorus, interspersed with a bass solo, as if heralds the end of the storyline and the oratorio as a whole:

The story ends in a minor key, with Xuanzong's recollection of Yang Guifei. From the plot's point of view, the oratorio's ending in this form looked quite logical. Nevertheless, Eternal Regret was continued: in 1972, it was finally completed (parts IV, VII, IX) by composers Lin Shengwen and Wei Hengzhan ${ }^{13}$. In 1992, the China Association for the Promotion of National Culture placed Eternal Regret in the list of the best works of the 20th century for its incredible charm and unique artistic value in the modern history of the Chinese choir. The birth of Eternal Regret initiated the creation of large-scale music 
Adagietto lamentando $(১-63)$

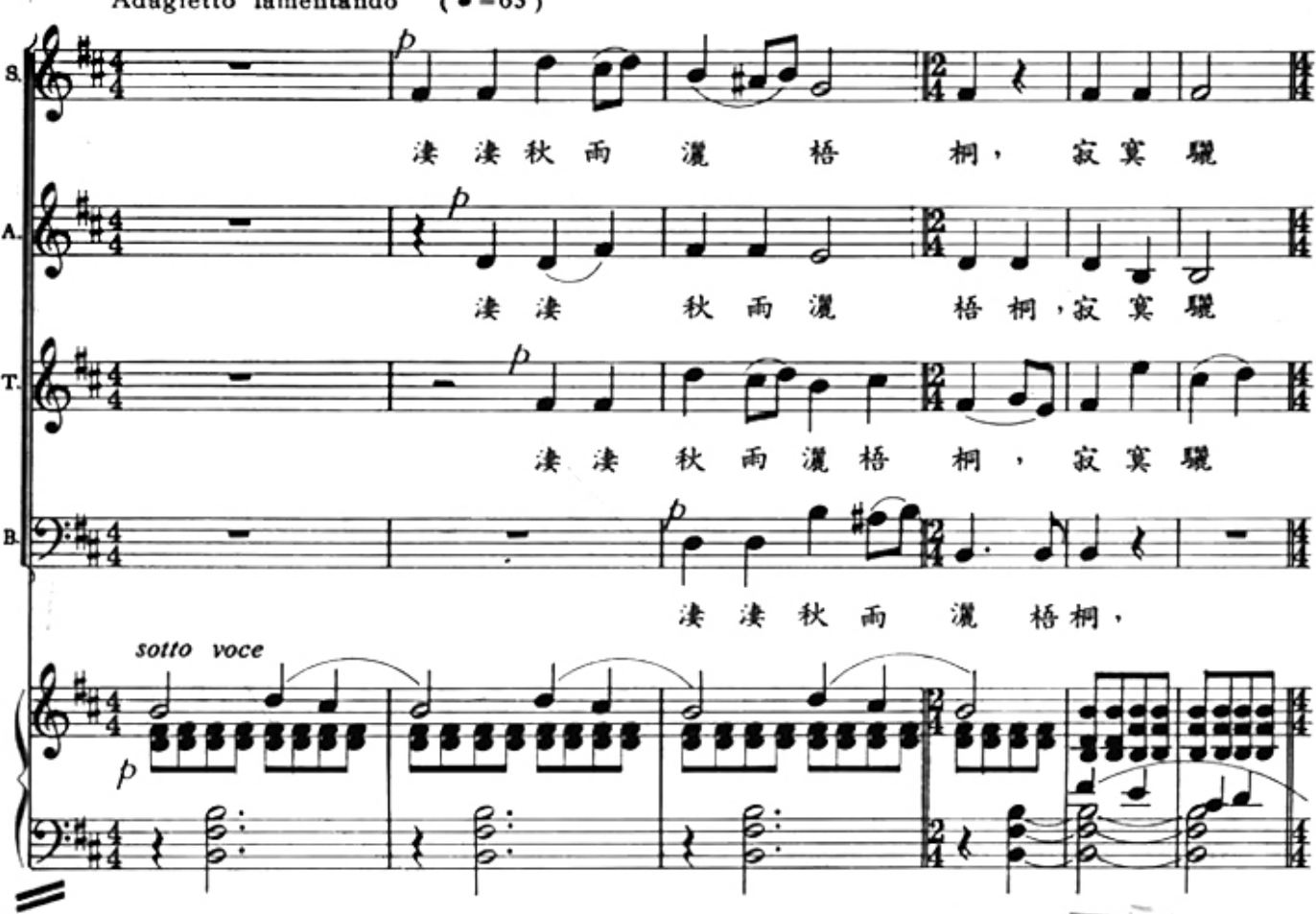

IIl. 12. An excerpt “此恨绵绵 无 绝 期". See ibid.

in the form of a Chinese oratorio and greatly influenced the future of the Chinese choir

Zhao Yuanjen once called Huang Tzi the most melodious composer ${ }^{14}$. And it is true - Eternal Regret has become one of the most relevant oratorios to perform.

Thus, the theme and content of the oratorio clearly reflect Huang Tzi's desire to influence the country's culture through the presentation of the pearls

of folk art in a new light - in the context of a significant vocal and instrumental composition. Huang Tzi was not only a great composer but also a true patriot. His focus on the development of national music gave us a large number of musical works of a new level, including the oratorio Eternal Regret. Having lived a relatively short life, he managed to do a lot, and what is most important - to bring the national Chinese choral culture to new heights while preserving the stylistic originality and main taining individuality.

REFERENCES:

1. 1. War Songs of Resistance against Japan. Huashan: Lit- 5. He Luyting. "Memories of Mr. Huang Tzi", Music scene. erature and Art Publishing house, 2003 (in Chinese)

2. Wang Yuhe. 1984. Contemporary Musical History of China. Beijing: People's Publishing House, 1984 (in Chinese)

3. Wu Gen-Ir. 2005. The Traditional Music of the Far East (China, Korea, Japan). St. Petersburg: Herzen Russian State Pedagogical University (in Russian)

4. Li Lantsing. 2008. "Study of the Creativity of the In(i) , 2-3. (in Russian)
1983. no. 8, pp. 3-8 (in Chinese)

6. 1983. no. 8, pp. 3-8 (in Chinese) Beijing: Folk Music (in Chinese)

7. Qian Renkang 2001. Sources of School Songs _- Shanghai: Shanghai Music Publishing House (in Chinese

Z Zhu Jincheng 1982 Chronology of Bai Juyi_-Shanghai: Shanghai Ancient Book Publishing House (in Chinese) Yu Qu 2006 . History of the Chinese Drame. (n Changhe Shangh 2006 . Historyof the Chinese Drama. - Shanghai Shanghai Education, vol 2, pp. 105-110. (in Chinese) Music Publishing House: 1957 (in Chinese)
Краснодарский государственный институт культуры Консерватория, Кафедра музыковедения, композиции и методики музыкального образования; преподаватель Саньминского университета (Sanming University), e-mail: luty25@163.com Саньмин, Китай ORCID0000-0003-1778-8255

DOI: 10.36340/2071-6818-2021-17-5-109-124

\section{ДИНАМИКА РАЗВИТИЯ ХОРОВОЙ КУЛЬТУРЫ КИТАЯ В 1930-Х ГОДАХ НА ПРИМЕРЕ ОРАТОРИИ ХУАНА ЦЗЫ «ВЕЧНОЕ СОЖАЛЕНИЕ»}

Аннотация: Хоровая музыка Китая является динамично развивающимся видом современного музыкального искусства. Научные труды, посвящённые китайской хоровой культуре, рассматривают 1930-е годы XX века как наиболее продуктивный период развития данной ветви музыкального творчества. В статье рассматривается фаза активного вхождения китайской хоровой музыки в сферу ораториального жанра, напрямую связанного с именем великого китайского композитора - Хуана Цзы. Здесь также освещены вопросы политической жизни страны в 1930-е годы, активно повлиявшие на создание общенациональных певческих движений и новых хоровых произведений в стране.

Ораториальный жанр, генезис которого отсылает нас к европейской религиозной музыкальной традиции XVII века, получает своё распространение на территории Китая благодаря массовому потоку китайской интеллигенции на территорию западных государств в течение всего начала XX века. Актуализация оратории и её интерпретация в новом свете в статье представлены как заслуга Хуана Цзы, гражданская позиция которого напрямую связана с желанием сохранения этнических начал в музыке Китая и их органичном дополнении приёмами западных композиторских техник. Проявивший себя не только как композитор, но также как теоретик и педагог, большую часть своей жизни Хуан Цзы посвятил воспитанию большого числа профессоров музыки, став инициатором прогрессивного подхода к музыкальному образованию. Его желание повысить уровень композиторской школы в Китае позволило обога-

Хоровое искусство Китая прошло долгий путь становления. Развиваясь от ранних форм школьных песен («сюэтанг юэгэ») до вершин ораториального творчества, оно получает осо- тить репертуар вокальной и инструментальной муыки характеристиками народного стиля.

Представленная в статье оратория «Вечное сожаление» является уникальным творением, органично сочетающим в себе этнический музыкальный материал и приёмы западной композиции. В истории императоБо Цзюйи), взятой композитором в качестве темы для либретто, прослеживается определённый символизм несущий в себе идейный замысел обращения к власти ной политики Гоминьдана. Таким образом, напрямую связанная с политическими катаклизмами и итоговым их воплощением в виде японо-китайской войны (1937 1945 гг.) оратория «Вечное сожаление» презентуется гражданские массы на борьбу с японскими захватчиками. Произведён анализ оригинальной поэмы Бо Цзюйи «вечное сожаление», а также осуществлен фрагментарный историко-стилистический и вокально-хоровой ности отдельных частей оратории - семь из которых являются завершёнными композитором. Опираясь на литературные источники и теоретические изыскания, изложенные в статье, автор утверждает особую роль оратории «Вечное сожаление» в истории и её далеского хора.

Ключевые слова: Хуан Цзы, Бо Цзюйи, хоровые жанры в Китае, музыкальная культура, оратория, «Вечное сожаление», композиторские техники.

бый прогресс в трагическую эпоху 1930-х го дов - период японо-китайской войны 1 . Первые 钱仁康.《学堂乐歌考源》.上海音乐出版社,2001:22. ра Сюань-цзуна и Ян-гуйфэй (на стихи танского поэта с целью демонстрации предполагаемых итогов неясв статье как консолидирующее ядро, вдохновляюще анализ оратории, раскрыты художественные особе ко идущее влияние на перспективы развития китай- 
хоровые произведения начала XX века, базирующиеся на заимствовании материалов из западных и японских песен, оцениваются теперь қак подготовительный этап к качественно новой ступени развития хоровой музыки. Лирический посыл, описание природных пейзажей и лёгкое настроение композиций сменяются усложнени ем идейных замыслов. Вместе с тем развивается музыкальное образование, открываются первые консерватории, искусство переходит в область написания сложных хоровых произведений, что способствует популяризации хорового искусства на территории страны ${ }^{2}$

Мукденский инцидент, произошедший 18 сентября 1931 года, и последующее за ним наступление японской армии послужили прецедентом для создания общенациональных «антияпонских певческих движений и движений «национального спасения» ${ }^{3}$. Композиторы страны, всячески содействующие коммунистической партии в борьбе с японскими захватчиками, определили смену вектора культурного развития в область написания массовых хоровых (антияпонских) песен. Вместе с тем анализ трудов современных исследователей, в числе которых У Ген-Ир, Цянь, Ренканг, Ван Жуйпу, Ван Юхэ и др., даёт обширный пласт информации по теме исследования хоровой музыки 1930-х годов, повествуя о данном пери оде как о времени актуализации военных песен и усложнении приёмов композиционного письма с последующим появлением жанра оратория.

Отдельное место в данной связи отводится великому китайскому композитору - Хуану Цзь (1904-1938 гг.), который остро откликнулся на призыв времени. Он явился одним из прямых инициаторов сОздания на базе Национальной консерватории музыки «Антияпонского союза и «Союза спасения нации». Вместе с тем компо зитор не раз высказывался о том, что китайское хоровое искусство должно стать независимым со своими особенностями и ярко проявленными национальными чертами ${ }^{4}$.

В преддверии описанных далее событий надо сказать, что Хуан Цзы имел феноменальное образование: окончив пекинскую подготовительную школу «Цинхуа», основанную для людей, соби рающихся продолжать обучение в Америке, он 2 У Ген-Ир. Традиционная музыка Дальнего Востока (Китай, Корея, Япония).- - СПб.: Российский государственный пе

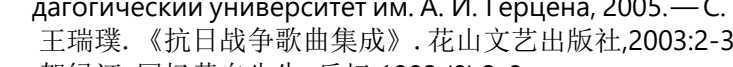
4 贺绿汀. 回忆黄自先生. 乐坛, 1983.(8):3-8. часто принимал участие в мероприятиях школы, организованных там при содействии христианской церкви. Влияние церковной музыки сказалось на том, что впоследствии он начал изучать западную музыку стандартным и систематическим способом, продолжая обучение в Оберлинском колледже и в Йельском университете (США). Получив в 1929 году степень бакалавра музыковедения и вернувшись на родину в 1930 году, он начинает работать в Национальной консерватории музыки (Шанхай) по приглашению композитора и основателя учебного заведения - Сяо Юмея. Обучая студентов гармонии, хоровым дисциплинам, контрапункту, инструментовке и композиции (в дополнение к истории музыки и сольфеджио), Хуан Цзы действительно был хорошо знаком с западными композиторскими техниками и не умаля их значения. Но тем не менее особенно важным считал сохранение культурного «кода» нации через его внедрение в музыкальную культуру страны.

Композитор всячески пытался популяризовать идеи о развитии собственной, национальной музыки, со сменой прежнего вектора развития, в котором отчётливо виделась тенденция к копированию западных и японских песенных мотивов. Ратуя за оригинальность собственных хоров Хуан Цзы был убеждён, что «...новая музыка может быть создана только теми композиторами которые, обладая знанием западных технолоий, разделяют судьбу китайского народа, его кровь и душу» 5 . Благодаря соблюдению содержания данных высказываний Хуан Цзы смог осуществить актуальную для китайского музыкального искусства миссию по сочетанию традиционно о национального творчества с новейшими западными жанрово-стилевыми тенденциями Как человек, в совершенстве владеющий основами западной композиции, Хуан Цзы исследовал традиционную китайскую музыку, баллады и стихи, желая создать новый национальный стиль хоровой музыки, способный повысить художественный уровень произведений и степень сложности в совокупности с почвенностью преподавания хоровых дисциплин в стране.

Буквально в первые дни после провозглашения о создании «Антияпонского движения» и «Движения за национальное спасение» в 1932 году Хуан Цзы создаёт монументальное сочинение первую китайскую ораторию для хора, солистов 5 李岗清. 探索创建我国民族乐派的先驱和一代宗师一黄自. 音乐 и оркестра «Вечное сожаление», где, несмотря на содержание, описывающее события давно минув ших дней, красной нитью проходит аналогия с тя жёлыми событиями 1930-х годов. Надо заметить, что идея создания «антияпонских» песен позволила Хуану Цзы создать не только первую в мире китайскую ораторию, но и инициировать созда ние целого пласта антияпонских песен ${ }^{6}$. Именно оратория «Вечное сожаление» действительно стала уникальным и масштабным произведением, первым в своём роде. Здесь автор умело обраща ется к стилистике немецкой песенной традиции европейскому романтизму, изящно обрамляя европейской композиторской техникой сюжет поэмы «Вечное сожаление» на стихи поэта эпохи Тан - Бо Цзюйи (772-846 гг.) (адаптированный под либретто современником Хуана Цзы - по этом-песенником Вэем Хэнчжанем).

Само «Вечное сожаление» представляет собой органичный синтез музыки и текста, а отдельные части произведения, презентующие мелодию, гармонию и оркестровку в национальном стиле, предстают весьма оригинальными и в наши дни.

Углубляясь в исследование сюжетной линии оратории, надо сказать, что содержание ори гинального сюжета (который не был искажён в оратории) переносит нас во времена правле ния императора Сюань-цзуна (685-762 гг.), являющегося непосредственным участником описанных событий 7 . Основное действие разворачивается в 736 году и начинается с повествования о смерти любимой наложницы императора Сюань-цзуна У-Хуэйфэй. Невозможность смириться с участью любимой приводит к тому, что император теряе покой. Вводная часть сюжета описывает момент когда император встречается с Ян Юхуань-женой своего сына Ли Мао. Ослепленный её красотой и умом, император, невзирая на этические манеры, присваивает ей придворный титул Гуйфэй ${ }^{8}$. Без памяти влюбившись в Ян Юхуань, им ператор оставляет все заботы о политических делах, ведя при этом весьма экстравагантную жизнь. Но несмотря на ухудшающееся положе ние в стране с повсеместной потерей авторитета власти, император продолжает попытки очаро вать Ян-гуйфэй: дабы показать свою преданность

$6 \quad$ В 1931 году Хуан Цзы создаёт первый «антияпонский хор “ хор подобного рода «Флаг веет по ветру».
桟仁康. 《黄自的生活与创作》. 北京: 人民音乐出版
社, 1997:50-53.

8 Титул жены императора-1-го ранга. и верность новой наложнице, Сюань-цзун назна чает Ян Гучжуна - старшего брата Ян-гуйфэй премьер-министром, а нескольким её сёстрам присваивает важные титулы.

Описывая личность Яна Гучжуна, Бо Цзюйи всячески демонстрирует негативные черты данного персонажа. Не имея должной квалификации для своей должности, но, напротив, всеми возможными способами нарушая правила правительства, Ян Гучжун активно взаимодействовал с придворными служащими, потворствуя коррупции и вымогательству. В конечном ито ге именно это приводит к массовому восстанию военных в 755 году, что ставит под угрозу поли тический порядок во всей стране. При активном недовольстве войск повстанцев эскорт императора Сюань-цзуна взбунтовался по пути бегств в Сычуань (в Мавейпо провинции Шаньси). О6винив семью Ян в хаосе, повстанцы казнили Ян Гучжуна и других членов семьи Ян. Войска также потребовали, чтобы Ян-гуйфэй была предана смерти. Чтобы успокоить армию и сохранить свой трон, императору Сюань-цзуну не остава лось ничего другого, как приказать ей покончить с собой 9 .

Ян Гуйфэй была одной из четырёх красавиц древнего Китая. Она получила признание и любовь императора за свою красоту, красота же стала и причиной её смерти. Титул, дарованный Сюань-цзуном молодой наложнице, стал непосредственной причиной катастрофы, произошедшей не только в семье, но и в стране. Здес хочется добавить, что в 806 году, когда Бай Цзюйи взялся за написание данной истории, его целью было обесценить Ян Гуйфэй, показав её с негативной стороны. Но казус великой наложницы состоял в том, что она превратилась в героя, к которому люди испытывали особенное сострадание. Длинное повествовательное лирическое стихотворение, в котором восхвалялась сама идея любви по итогу стало культурным памятником с определённым политическим подтекстом, заставляющим сопереживать героям сквозь века.

В дополнение хочется отметить, что даже у Бо Цзюйи помимо описания любовной трагедии, развернувшейся между императором и женой его сына, прослеживается рассмотрение таких проблем, как социальное неравенство: изысканность императорской жизни в противовес крайней бед-

9 朱金城.《白居易年谱》。上海: 上海古籍出版社, 1982:100-108 
ности простого народа. Оригинальное стихотворение Бо Цзюйи состояло из трёх частей. Первая часть была посвящена любовной истории Сюань-цзуна и Ян-гуйфэй. Вторая часть содержала описание восстания, вызванного поведением им ператора Сюань-цзуна, а также мятеж повстанцев и последующую смерть Ян-гуйфэй. В сцене смерти Ян-гуйфэй поэт точно описывает чувства персонажей, отражая внутреннюю борьбу и отчаяние императора Сюань-цзуна, не желавшего убивать свою возлюбленную, но вынужденного это сделать. Эта личная трагедия по факту и породила собой название поэмы - «Вечное сожаление».

Последующие картины третьей части описывают возвращение императора во дворец в Чанъане (ныне Сиань). Грусть и тоска по Ян-гуйфэй невозможность вернуть её, уносит императора в страну мечты. В последней части стихотворения поэтом была задумана яркая сказочная страна, в которую попадает император Сюань-цзун и где Ян-гуйфэй жива. Эта встреча превращает любовную трагедию, произошедшую в реальном мире, в историю, полную счастья, в мире иллюзорном ${ }^{10}$.

Но такой оригинальный выбор истории Сюань-цзуна и Ян-гуйфэй в качестве темы для либретто был сделан композитором Хуаном Цзы не ради восхваления пронзительной истории любви, скорее это было обращение к власти с целью демонстрации итогов неясной политики Гоминьдана, которая может привести к национальной катастрофе. Два отрывка мужского хора в третьей и пятой частях оратории лучше всего пере дают беспокойство людей в эпоху 1930-х годов, именно Они являют собой патриотический приименно они я

Углубляясь в непосредственное содержание оратории «Вечное сожаление», важно заметить, что изначально она была разделена на десять частей - название каждой части соответствовало нескольким строкам стихотворений Бо Цзюйи ${ }^{1}$ Но из десяти предполагаемых Хуан Цзы успел сочинить семь (I, II, III, V, VI, VIII, X), что в принци пе не сказалось на целостности оригинального замысла: семь законченных частей (которые будут описаны ниже) смогли передать основное содержание и сцены поэмы с её сюжетной сутью

10 Tam жe.
11 钱仁康. 《黄自的生活与创作》. 北京: 人民音乐出版
社 1997.70.

и интегрированной структурой. Три незаконченные части предполагали стать солирующими номерами с отсутствием хоровых партий,-скорее вего, это и сказалось на их незаконченности.

В первой части «Звуки небесной музыки уносимые ветром вдаль» Хуан Цзы использу ет простую трехчастную форму. Часть написана для четырёхголосного смешанного хора, что аллегорично отображает атмосферу дворцо вого праздника, которым начинается действие оратории. Особое внимание здесь отводится рас крытию оркестровой партии: серия стаккато, которая слышится в аккомпанементе в 1-м периоде и еле слышимые аналогичные отголоски в разных частях 2 скошность императорского дворца, где танцуют изящные фрейлины:

Рис. 1. Отрывок «仙乐风飘处处闻》 с демонстрацией серии стаккато в оркестровой партии, см. Вэй Хэнчжань, Хуан Цзы. Вечное сожаление.Пекин: Музыкальное издательство, 1957.

Вторая часть «Во дворце вечной молодости 7-го числа 7-й Луны» построена с использованием сложной трёхчастной формы и начинается со вступления оркестра, передающего тему любви:

Рис. 2. Отрывок «七月七日长生殿》, см. Вэй Хэнчжань, Хуан Цзы. Вечное сожаление-— Пекин: Музыкальное издательство, 1957.

Вслед за аккомпанементом вступает трёхголосный женский хор, отображающий всю красоту спокойной тёплой ночи. На их фоне соло сопрано и баритона - императора и Ян-гуйфэй - повествуют нам о клятве возлюбленных друг другу и тяжёлых муках их расставания:

Рис. 3. Отрывок вступления трёхголосного женского хора См. Вэй Хэнчжань, Хуан Цзы Вечное сожаление.-Пекин: Музыкальное издательство, 1957.

Рис. 4. Партия Ян-гуйфэй, см. там же. Рис. 5. Партия императора, см. там же.

Третья часть «Боевые барабаны в Юйяне, сотрясающие Землю» отличается от первой и второй воинственным характером, передающим боевой настрой. Здесь Хуан Цзы использует трёхчастную форму для изображения сцены с военными, при ближающимися к столице: сначала мы слышим теноровую партию (имитация сцены приближения повстанческих сил к столице), а затем, вторящий им, четырёхголосный мужской хор. На протяжении всего хора прослеживается художе ственное изображение гнева повстанцев, выра- жающих недовольство поведением императора и бездействием правительства в текущих делах В этот раздел Хуан Цзы внедряет полифонию, а мелодика произведения отражает нарочитую драматичность:

Pис. 6. Отрывок 《渔阳馨鼓动地来》, см. Вэй Хэн чжань, Хуан Цзы. Вечное сожаление.- Пекин: Музыкальное издательство, 1957.

Пятая часть «Император был бессилен, когда гвардия не слушалась его» написана для четырёхголосного мужского хора, выражающего протест войск повстанцев с требованием о каз ни, Ян-гуйфэй. Мы можем сказать, что именно здесь видится кульминация всей оратории. Интенсивность динамики варьируется от ррр до fff, что характеризуется как апогей обиды и гнева. Это чувство согласуется с антияпонским энтузиазмом народа в 1930-е годы. Так метафорич но Хуан Цзы заявляет о решимости народа всем сердцем противостоять Японии:

Рис. 7. Отрывок 《六军不发无奈何》 с иллюстрацией динамики, см. Вэй Хэнчжань, Хуан Цзы. Вечное сожаление.-Пекин: Музыкальное издательство, 1957.

Рис. 8. Отрывок 《六军不发无奈何» с иллюстрацией динамики, см. там же.

Последующая, шестая, часть «Самоубийство Ян-гуйфэй перед императорским конём», повествует о трагической кончине наложницы императора, который был вынужден приказать Ян-гуйфэй покончить с собой, дабы сохранить трон императора. Здесь солирующая партия отдаётся сопрано, а вся часть наполнена особым трагизмом, характеризующим окончание любовной истории императора и его возлюбленной:

Pис. 9. Отр чжань, Хуан Цзы. Вечное сожаление-П Пекин: Музыкальное издательство, 1957.

Оставшиеся две части «Сказочная гора в океане небывалой земли» (VIII) и «Вечное сожаление о невыполненной клятве» (X) представляют для нас особый интерес, так как именно здес Хуан Цзы реализует искусные западные композиторские приёмы, что придаёт оставшимся двум частям изысканное художественное очарование. Тяготея к различным полифоническим техникам и заимствуя их из европейской культуры Хуан Цзы закладывает основы вокальной полифонии и гармонического мышления в структуру китайского хора, что отчётливо прослеживае ся в восьмой части «Вечного сожаления», Здесь композитор использует двоичную форму и задействует трёхголосный женский хор, органич но вкрапляя народную мелодию «Цинпин дяо» ${ }^{12}$ позитор применяет пентатонику — она звучи в оркестровом аккомпанементе, придавая мелоии определённое очарование и загадочность:

Рис. 10. Отрывок «山在虚无缥䍀间》 с иллюстрацией народной мелодии «Цинпин дяо» в оркестровой партии, см. там же.

Слышится смех фей священного острова Пэнлай, исполняемый трёхголосным женским хором. Струнный аккомпанемент, который деля между собой первая и вторая скрипки - чистый и мягкий, создающий фантастическую атмосфе ру страны чудес. Сочетание народных песенных мотивов с западными композиторскими техниками погружает слушателя в атмосферу несбыточной сказки.

Рис. 11. Отрывок «山在虚无缥纱间》, см. ВэЙ Хэнчжань, Хуан Цзы. Вечное сожаление - Пе кин: Музыкальное издательство, 1957.

Десятая часть - заключительная. Четырёхголосный смешанный хор, перемежающийся с соло в басу как бы знаменует об окончании сюжетной линии и оратории в целом:

Pис. 12. Отрывок «此恨绵绵无绝期》 CM. там же

История заканчивается в миноре воспоми нанием Сюань-цзуна о Ян-гуйфэй. С точки зре ния сюжета, окончание оратории в таком виде ыглядело вполне логичным. Но всё же «Вечное сожаление» получило своё продолжение: окончательно (части IV, VII, IX) оно было завершено в 1972 году композиторами Линем Шэнвэнем и Вэем Хэнчжанем ${ }^{13}$. За своё великое очарование и особую художественную ценность в современной истории китайского хора в 1992 году Китайская ассоциация содействия национальной культуре внесла «Вечное сожаление» в список лучших произведений XX века. Рождение «Веч ного сожаления» положило начало созданию тайского хора

Чжао Юаньжэнь однажды назвал Хуана Цзы самым певучим композитором ${ }^{14}$, и это действи-

12 Народная китайская мелодия, пользующаяся особой по пулярностью в эпоху Тан.

李岗清. 探索创建我国民族乐派的先驱和一代宗师-黄自. 音乐 14 Там же. 
тельно так - «Вечное сожаление» стала одной из самых актуальных для исполнения ораторий.

Таким образом, тематика и содержание оратории чётко отражают желание Хуана Цзы повлиять на культуру страны через презентацию жемчужин народного творчества в новом свете в контексте крупного вокально-инструментального сочинения. Хуан Цзы был не только великим композитором, но и истинным патриотом. Именно его сосредоточенность на развитии национальной музыки подарила нам большое количество музыкальных произведений нового уровня, в том числе и ораторию «Вечное сожаление». Прожив сравнительно недолгую жизнь, он сумел сделать многое, и что самое главное - вывести национальную китайскую хоровую культуру к новым вершинам, сохранив при этом стилевую самобытность, индивидуальность и неповторимость.

\section{БИБЛИОГРАФИЯ:}

1. 王瑞璞. 《抗日战争歌曲集成》. 花山文艺出版社,2003. Ван Жуйпу. Военные песни сопротивления Японии.- Хуашань: Изд-во литературы и искусства, 2003.

2. 汪毓和. 《中国近现代音乐史》. 北京: 人民音乐出版社， 1984. Ван Юхэ. Современная музыкальная история Китая.-Пекин: Народное издательство, 1984.

3. У Ген-Ир. Традиционная музыка Дальнего Востока (Китай, Корея, Япония).-СПб.: Российский государственный педагогический университет им. А. И. Герцена, 2005.

4. 李岗清. 探索创建我国民族乐派的先驱和一代宗师-黄 自. 音乐艺术: 上海音乐学院学报,2008,(2):2-3. Ли Ланьцин. Изучение творчества новатора и великого основателя национальной музыкальной школы Китая - Хуан Цзы // Музыкальное искусство. — 2008. № 2.-C. 2-3.
5. 贺绿汀. 回忆黄自先生. 乐坛, 1983.(8):3-8. Хэ Люйтин. Воспоминания г-на Хуан Цзы // Музыкальная сцена. - 1983. - № 8.- С. 3-8.

6. 钱仁康. 《黄自的生活与创作》. 北京: 人民音乐出版 社,1997. Цянь, Ренканг. Жизнь и творчество Хуан Цзы.-Пекин: Народная музыка, 1997.

7. 钱仁康. 《学堂乐歌考源》. 上海音乐出版社,2001. Цянь Ренканг. Источники школьных песен.- Шанхай: Шанхайское музыкальное издательство, 2001.

8. 朱金城. 《白居易年谱》. 上海: 上海古籍出版社, 1982. Чжу Цзиньчэн. Хронология Бо Цзюйи.- Шанхай: Шанхайское издательство древних книг, 1982.

9. 余秋雨. 《中国戏剧史》. 上海: 上海教育出版 社,2006:105-110. Юй Цюй. История китайской драмы / Цюй Юй.- Шанхай: Шанхайское образование, 2006.-T. 2.-C. 105-110.

10. 韦瀚章, 黄自. 《长恨歌》. 音乐出版社, 1957. Вэй Хэнчжань, Хуан Цзы. Вечное сожаление.- Пекин: Музыкальное издательство: 1957. 